\title{
Editorial: Knowing Theatre Inside Out
}

\author{
ELAINE ASTON
}

Traditionally, the role of theatre and performance scholars is to examine theatre from critical and theoretical perspectives that adopt an outside-in approach. That is to say, our vantage point locates at some disembodied, critical distance from the process and the practice, from the making and the moment of showing. Increasingly, however, there are signs of inside-out approaches to theatre where avenues of theatre and performance enquiry are shaped by means of getting closer to practice. The first three articles brought together in this issue have their own, distinctive inside-out routes to theatre and performance knowledge.

In setting out to argue that HIV/AIDS performance is socially and politically as urgent today as it was in the 1990s, Alyson Campbell couples queer theory, performance and AIDS literature with her directorial perspectives on the two shows that case-study her discussion: Reza Abdoh's Bogeyman and Lachlan Philpott's Bison. As assistant director to Abdoh in 1991 at the Los Angeles Theatre Center and as the director of Philpott's play for Belfast's OUTburst Queer Arts Festival in 2009, Campbell is able to weave her insider's knowledge of how the shows worked in practice with her critical-political reflections. At pains to reveal the work of Abdoh and Philpott as politicizing by means of their respective (very different) experiential or affective dramaturgies, Campbell traces how the shows' interventionist, HIV/AIDS awareness-raising strategies are shaped in and by their sociohistorical moments. Ultimately, Campbell lays claim both to the need for a remembering rather than a forgetting of 'HIV/AIDS subjectivities on the contemporary Western stage' and 'a continual reimagining of a queer dramaturgy that can find forms to reflect the complexities of these subjectivities'.

The geographies of Campbell's discussion locate in the US, Northern Ireland and Australia (on account of the contexts in which the plays were written or produced). Daniel Johnston's article and the co-authored contribution from Andrew Filmer and Kate Rossmanith return to Australian theatre. What both of these articles share is an interest in looking at theatre from behind the scenes: Johnston from the rehearsal room, Filmer and Rossmanith from rehearsal and backstage spaces. Johnston's 'Theatre-Making as Aletheia' revisits Gay McAuley's earlier article for Theatre Research International in which she case-studies a workshop by the South Australian theatre company Brink for a production of Sarah Kane's 4:48 Psychosis. ${ }^{1}$ Johnston has a complementary, but different, objective in mind: to conceptualize the rehearsal process in Heideggerian terms as a process of 'truth-revealing' (aletheia). A participant observer of the workshop that took 
place at the University of Sydney in 2004, Johnston's insider views of the rehearsal form the basis for his subsequent, philosophical reflections on 'performance-making as a process of truth-discovery'. In brief, getting closer to practice, to the physical, sensory, embodied explorations between the performers in the rehearsal room, allows him to think philosophically about how it is that 'theatre space can be a distinctive kind of place where truth can be revealed when combined with the creative vision of theatre practitioners'.

Filmer and Rossmanith argue that the creative labour that takes place in 'offstage spaces' has not received the academic theatre attention it deserves. In their shared view, what this critical neglect overlooks is the valuable way in which this unseen labour is seminal to not only 'the making of theatrical performance but also the making of theatrical performers'. Their discussion is grounded in months of fieldwork carried out in theatres in Sydney: in their placed observations of practitioners in rehearsal and backstage spaces. To make critical sense of their accumulated inside knowledge of the day-to-day practices of performers, Filmer and Rossmanith address their ethnographic theatre research via the notions of 'orientational metaphor, tactical inhabitation and training zones'. Although these backstage enquiries are very different to Johnston's in terms of both critical apparatus and theatre subjects, to consider these articles side by side is to emphasize the importance each attaches to opening up rehearsal rooms and backstage spaces as important sites of enquiry into 'space and actor formation'.

Questions of 'actor formation' are taken up in the next two articles, each with its own specialist interest in understanding the 'making' of the performer. David Kornhaber turns to philosophy to enquire after the issue of selfhood prominent in a range of twentieth-century theatre and performance traditions. Opening with attentions to ideas of selfhood touched on by Forced Entertainment director Tim Etchells, and working back through Philip Auslander's critique of logocentrism, Kornhaber moves to argue Nietzsche's philosophy of performance and selfhood as a means to understanding 'a model of performance where there is only ever the refashioning and never the original self that is refashioned'. Identity issues resurface in Marlis Schweitzer's article on the vaudeville singer Harry Lauder, but in a very different way as she traces the carefully crafted construction of the artist as 'the canny Scot' in order to illuminate how and why this stereotype was mobilized in the interests of Lauder's career and in the context of early twentieth-century vaudeville. Specifically, she traces how Lauder's 'performance of thrift' served both to allay the fears 'that men, as well as women, were becoming mere cogs in the machine of corporate Broadway capital' and to endorse 'a bold spectacle of nationalist sentiment at a time when Scottish Americans were reclaiming their Scottish heritage'. Theoretically informed by Appadurai's notion of 'commodity', Schweitzer's attentions to the commodity status of the male performer serve as a valuable addition to the rich field of feminist scholarship that has worked to expose the commodification of female performers.

And, finally, from vaudeville and the Scottish American diaspora of the early twentieth century, we move to an overview of current trends in the field of Irish theatre studies. Introduced and edited by Melissa Sihra, this collaborative submission surveys the field, 'revealing the ways in which discourses of nationalism, sexuality, gender, 
class and the family are being renegotiated'. Collectively, Christopher Collins, Mary Caulfield, Shonagh Hill, Fintan Walsh, Cormac O’Brien and Aoife McGrath explore the paradigmatic shifts reshaping Irish theatre and performance.

This composite 'dossier' contributed to by early-career scholars signals the journal's interest in group submissions under the rubric of our 'new developments for TRI' as originally announced in Freddie Rokem's editorial in March $2008(33,1)$. To reiterate: keeping in mind our overarching interest in enhancing the global scope of the journal, we look forward to receiving more dossier proposals that report on fields of theatre and performance research, on innovative performances and on research projects. In other words, we invite our readers to keep them coming!

NOTE

1 Gay McAuley, 'Not Magic but Work: Rehearsal and the Production of Meaning', Theatre Research International, 33, 3 (2008), pp. 276-88. 